\title{
The Tao of Retirement: Reflections on Some Hidden and Unexpected Effects of Retirement on Health and Happiness [1]
}

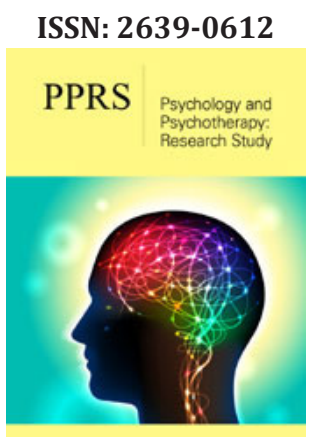

*Corresponding author: Warren B, Drama in Education and Community, Canada

Submission: 梅 September 01, 2020

Published: 㘹September 14, 2020

Volume 4 - Issue 2

How to cite this article: Warren B, Hind C. The Tao of Retirement: Reflections on Some Hidden and Unexpected Effects of Retirement on Health and Happiness [1]. Psychol Psychother Res Stud. 4(2). PPRS. 000582. 2020 DOI: 10.31031/PPRS.2020.04.000582

Copyright@ Warren B, This article is distributed under the terms of the Creative Commons Attribution 4.0 International License, which permits unrestricted use and redistribution provided that the original author and source are credited.

\section{Warren $\mathrm{B}^{*}$ and Hind C}

Health is a state of complete physical, mental and social well-being and not merely the absence of disease or infirmity

\begin{abstract}
Retirement presents different challenges for each individual both in planning for and accepting their retirement. This article, written as a personal narrative, presents some of the hidden and unexpected mental, emotional, and physical effects of retirement on the health and well-being of retirees and their family. It discusses financial planning, health, the nature of time, and friendship, all from a Taoist perspective.
\end{abstract}

Keywords: Retirement; Stress; Happiness; Retirement time; Financial planning; Health maintenance; Taoism

\section{Setting the Scene}

\section{No two snowflakes are the same}

Almost without exception, no two people are the same. We all have a different genetic make-up and life experience which affects everything that makes us who we are. Factors such as gender; sexual orientation, relationship status; race, ethnicity, socio-economic status; geographic location - where we live, and its cultural and political environment: and a host of other characteristics, contribute to the experience of aging differently for everyone. These factors and their interconnections mean that retirement presents different challenges for each individual [2,3]. Four years ago, I (BW) accepted early retirement from my position as a University Professor, a job I had excelled at, and for the most part enjoyed, for over 35 years. However, over a short three-year period I became increasingly disillusioned. During this time my best friend, my mother, and two of my cats died, I was no longer enjoying teaching and I did not want to die at my desk. I negotiated a buyout from my university, with a reduced pension. I had several projects planned that I was sure would keep me busy and top up my finances. I really didn't comprehend the physical and emotional effects retirement would have on my life. To be honest, it has taken me 4 years to adjust and start to accept these changes. What follows are reflections on one person's retirement experience.

\section{And then I retired}

We leave something of ourselves behind when we leave a place.

In retirement, my sense of the world and the people who inhabited it changed. And time, friendship, finances, and health all took on greater significance. On the day a person retires they do not magically change! However, their circumstances do, creating challenges that are difficult to prepare for. My personal landscape changed overnight. No longer did I run up and down stairs several times a day, teach 3 hours of movement weekly, or have throngs of students hanging on my bon mots and dropping by my office to share their academic and personal lives. During our working lives, most adults identify with and gain a sense of identity from their job. On first meeting people still ask: "Who are you? And what do you do?" So, in retirement WHO are you? In retirement one's sense of the world changes both literally and 
metaphorically. Sometimes it may be hard to feel that retirement isn't simply 'slacking' or being 'useless' and this affects both mental and physical aspects of health and well-being. In retirement I was left wondering, who am I? I wanted to rebuild a sense of my identity and self-esteem, but my working experience was my reference point. Then the penny dropped, and I started to revisit the Taoist teachings which had guided my 50 years of martial arts practice and influenced the way I lived my working life.

\section{The Changing Nature of Time}

\section{No man ever steps into the same river twice}

I was reminded that Taoists see life as a river that continually flows forward. You cannot dwell on the past, for it is old water that has already flowed under old bridges. You must live in this moment and experience it fully. If patience is a virtue, in retirement, I learned I am not virtuous. Without the structures and demands of the work week, I found myself operating on Retirement Time. Replying to communications almost instantly. Expecting others to do the same. In retirement, time is a contradiction. Every day is full of opportunities. There are few fixed points, so it is sometimes hard to remember the day of the week. Trips to a doctor or dentist, simply shopping- now become major events to look forward to. The reverse of this is that your days are numbered. One of the hardest things has been dealing with several unexpected deaths of friends. All sadden me and remind me of my own mortality. Each day is a gift, but I am constantly reminded that the number of days left in my life are diminishing.

\section{Losing friends, the effect(s) of drifting away and distance}

Every moment that went before leads to this moment, and this moment will lead to each one that follows

Prior to retiring, my spouse, Deb and I chose to move to a small apartment away from the town where we worked. We enjoy each other's company, talk and laugh a lot-which is good because we were now living together 24/7! Still we felt a pull to reconnect and spend time with friends. One of the first things I noticed in retirement was my circle of friends changed. People I spent long hours with as colleagues now had no time for me, as we had nothing in common to discuss. I came to refer to these people as Situational Friends.

Harder to deal with were Old Friends who, for various reasons, had drifted away. This was particularly disturbing when these friends are those you grew up with during childhood and adolescence. My True Friends, many of whom live long distances away, stay in touch. But as we have all moved several times it is more difficult to visit. Luckily modern technology allows us to communicate via videocalls such as ZOOM, Face Time \& Skype.

\section{Creating a new sense of community}

Sometimes you want to go, where everybody knows your name.

In retirement the people who inhabited the work world change and friendships take on greater significance. However, bonds forged earlier in life break down and many friends fade away. Indeed, sometimes the landscape completely changes when significant players in our lives die. Many people in retirement need to build a new sense of community. A new sense of place and belonging. For environmental and health reasons, the first thing we did when we retired was to get rid of our cars. We no longer needed them to drive $50 \mathrm{kms}$ to work, we wanted to walk more, and the bus service where we live is good, although quite slow. Most of its riders are seniors and take the bus to simply get out of the house and speak with and connect with other people. However very soon it became clear that on the bus, everybody knows your name and your business! Soon people learnt that I was a retired university professor and had worked as a therapist. They asked me many questions about their personal predicaments and expected that I had solutions. Sometimes it made me feel wanted, but most often I felt like I was living in a Charlie Brown cartoon holding a sign saying, "the doctor is in". Either way I had become a member of this bus community.

\section{Healthy aging and retirement}

\section{If you ain't got your health, you ain't got nuffin.}

The process of aging and its effects on body and mind affect retirement plans at least as significantly as finances. Being, and staying healthy is of great significance to individuals as they approach and enter their retirement. Increasingly in developed nations people spend large amounts on vitamins and supplements to try to slow down the effects of aging and there are programs that promote physical health, brain health and so on. On entering retirement, both Deb and I were healthy. However, within the year Deb experienced carpal tunnel syndrome necessitating surgeries on both wrists. Soon after, while in Thailand, she could not move without a great deal of pain. When we got home, we discovered she had developed rheumatoid arthritis. Fortunately, it was caught early and is now successfully managed. In retirement, I dutifully follow my lifelong regime of martial arts and yoga practice at home [4]. I remain fit for my age, but the inactivity in retirement coupled with my love of cooking and eating means that my weight creeps up. Even 5 extra pounds exacerbates back and knees injuries I sustained playing sports when I was young and immortal! Some mornings, getting up from floor from Yoga can be a challenge. This is not as bad when we are travelling as I eat more simply, and we swim and walk more. When home, I now must be conscious of food portion size and exercise conscientiously.

\section{Adapting to financial change}

\section{Cut your coat according to your cloth.}

There is a lot written nowadays about planning for retirement. Entire industries are devoted to financial planning and the notion of not outliving your money. Often missed in all of this is perhaps our greatest asset in retirement, time. What can be overlooked is that just as we plan what to do with our money, when we retire each of us makes plans and has different priorities about what to do with our time. This is no different in some ways to when we were working but now, we have more time to do those things. How one adapts to change greatly affects the retirement experience and by extension one's happiness and health. Retirement presents different 
challenges depending on circumstances and contexts and no two strategies are the same. There is often a gap between planning, making strategies and wish lists, and the actual experience of retirement. Even a well-planned retirement presents unforeseen events, which create stressors that affect health, happiness, and overall well-being. Deb and I retired with a shared desire to travel. To this end, unlike close friends who live by the conventional wisdom that you must retire debt free, we decided that paying interest on debts was the cost of doing business. I suppose I was influenced by my Dad who always says, you're a long time dead! Enjoy your life while you have your health. He pursued a live now, pay later life and travelled the world looking for new adventures e.g. his 80th birthday was spent walking the Great Wall of China. Our approach is more balanced than my Dad's in that it follows suggestions from a financial advisor to divide your income into thirds-one for existing debt, one for later, and one for now. When in doubt always pay yourself before creditors!

\section{The Dubai Debacle}

That which does not kill me ... makes me stronger?

That which does not kill me makes me stronger? When, I retired my income dropped. The 3 projects I planned to help top up the shortfall were torpedoed by unforeseen events. I found myself with nothing on my plate-never a good situation for me. I started to apply for jobs to fill my time, supplement the household budget, and link to travel opportunities. I secured a few positions that went well but then I applied for what appeared to be a great job with excellent pay in Dubai. However, I forgot the old saying, if it seems too good to be true, it usually is. I was the victim of a cleverly crafted scam. The job offer required me to send documents and money for various visas for which I was assured I would be reimbursed. This did not seem odd, as it was the standard practice, I had experienced working in Singapore, China, and Thailand. However, there was no job in Dubai, and afterward my father's oft-used words haunted me "for such an intelligent man, how can you be so stupid?!" Yet I am not alone! On talking with bank tellers, police, and the Canadian anti-fraud agency, I was surprised by how many people are defrauded of large sums of money every day. Everyone I spoke with said these scams are getting slicker and more technologically advanced. Even police officers in anti-fraud units have been scammed. However, none of this made me feel any better. The scam defrauded us of our savings and created an additional mountain of debt! It made living on a fixed income harder and created immense stress.

\section{Managing stress}

Don't think of the problem think of the solution...! there is always a solution but not necessarily the one you want.

Communication is essential for successful relationships and this is magnified in stressful times. The Dubai Debacle meant we were now drowning in debt! Luckily, Deb and I talk about everything. We made joint decisions about how to cope with our situation. We decided to downsize and declutter. We sold off everything that wasn't locked down. We reduced our daily expenditures to bare essentials. Deb increased efforts to bring in business through her boutique travel agency, something she had developed part-time while working full-time in healthcare. The stress experienced during the Dubai Debacle was extreme. This is a MESS! Need re positioning. I stubbornly refused to enter a consumer proposal or declare bankruptcy! I experienced moments of extreme anxiety which created heart palpitations and dizziness. I dreaded the phone ringing as I did not want to once again explain my stupidity to creditors. My regular practice of Qigong and Yoga, supplemented with the occasional very low dose of Ativan, helped regulate my anxiety. We started to shop at cheaper supermarkets and bought marked down produce from local markets Through careful budgeting we always had food on the table. I made healthy meals from scratch, grateful my mother and my grandmothers taught me to cook like my poor Eastern European ancestors. Thankfully through this constant communication and lots of laughter, careful budgeting, and a healthy lifestyle we have managed to successfully pull ourselves out of the morass of debt without succumbing to ill health.

\section{... And Then COVID Struck}

\section{Something Wicked This Way Comes}

The COVID-19 Pandemic has altered the lives of millions of families. The death toll worldwide is continuing to climb. Many people have seen their incomes evaporate and they have been reduced to accepting government handouts to survive. Individuals close to retirement have seen their plans disintegrate. It has left individuals it has touched physically and emotionally scarred. Those who caught the disease and survived are left with a multitude of physical health problems. Many more still are experiencing PTSD or other mental health issues. The long terms human and financial costs of the pandemic have yet to be fully calculated. Retired seniors, especially those with pre-existing conditions saw their savings take a hit and their best laid plans all but evaporate. For Deb and I our plans to travel in retirement were completely upended. Winter trips were booked and rebooked several times and finally cancelled. The most upsetting of these was a trip to see my health compromised 92year-old Dad and a dear friend who was dying, My Dad died this last week! and so I changed this sentence to reflect this during this pandemic. For those living in their own homes, they were afraid to go to the stores. Unable to buy basic necessities such as toilet paper. While those living in seniors residences and long-term care facilities, were the victims of decades of successive governments' neglect vis-a-vis maintaining and overseeing basic healthcare delivery in such facilities. This translated into viral outbreaks and large-scale deaths. All over the world people died by the hundreds in isolation, separated from their family, while callous governments simply saw these elderly people as collateral damage in a political game of smoke and mirrors.

During this time, I was lucky enough to live in Canada, where our governments managed the pandemic fairly well. I was able to go to stores and pick up groceries, as long as I took suitable precautions. Washing my hands and face after visiting the store, wearing a face mask and observing social distancing protocols have meant that we have remained healthy and Canada has managed to 
keep the virus from overwhelming our communities. However, the lessons of the Spanish Flu must not be forgotten. For while we have managed to flatten the curve and reduce the spread of the virus, it is still infecting and killing people. Schools and bars are re-opening BUT people are forgetting to observe the simple health protocols that enabled countries to re-open. Spikes in the number of cases and deaths are increasing again and most of the world remains closed for business and travel.

\section{Final thoughts}

$$
\text { Do not force Tao ... }
$$

The Universe unfolds as it must, not as you want

In a sense each retiree has their own Tao of Retirement. Each individual's attitude towards this new situation is affected by their attitudes and beliefs and their view on life, which affects the ability to cope with changes and builds resilience. For me, retirement has been challenging and hard to accept. In the beginning I was lost and wanted life to provide the same stimuli and structure that I had known during my working life. Slowly I have adapted to my changed situation. I credit a large part of this to the support and constant companionship provided by being in a loving and happy relationship. During the pandemic Deb and I moved to an apartment building for adults. Many residents are well over 65 and a good number are health compromised. During our swim time, we talk to people in the pool, while trying to keep social distance, but otherwise we keep very much to ourselves.
We do not feel as isolated as we did at the beginning of the crisis but haphazard use of masks in social spaces and the tendency for some people, partially because of hearing deficits, to get too close is a little worrying at times. We eat healthily. I continue to cook from scratch using the TCM 5 colours approach and limit salt, sugar and saturated fats as much as possible. I still perform my daily martial arts and yoga routines and we swim every day. We remain in good health for our age. I feel that through our constant communication, and working together on every problem that has arisen, we have weathered the health challenges, financial hardships we have had to endure. By careful budgeting and simply accepting each moment as it is presented to us, we have rebuilt our financial health, reduced our stress, and are now enjoying our retirement to the full.

\section{References}

1. This article is based on an essay originally prepared for The Lancet. Its themes will be expanded in our upcoming book: Warren B, \& Hind C, The Tao Of Aging: Some Hidden And Unexpected Effects Of Retirement On Health And Happiness; Rocks Mills Press.

2. Morley JE (2017) Vicissitudes: Retirement with a long post-retirement future. Generations 41(2): 101-109.

3. Osborne JW (2012) Psychological effects of the transition to retirement. Canadian Journal of Counselling and Psychotherapy 46(1): 45-58.

4. Warren B (2019) No need to go to a gym: Practicing qigong and yoga in small spaces at home-a personal reflection. International Journal of Complementary \& Alternative Medicine 12(4): 135-139. 